\title{
High spectral response heteroleptic ruthenium (II) complexes as sensitizers for dye sensitized solar cells
}

\author{
M CHANDRASEKHARAM ${ }^{\mathrm{a} *}$, Ch SRINIVASARAO ${ }^{\mathrm{a}}, \mathrm{T} \mathrm{SURESH}^{\mathrm{a}}, \mathrm{M}^{\mathrm{A}}$ ANIL REDDY ${ }^{\mathrm{a}}$, \\ $M_{\text {M RAGHAVENDER }}^{\mathrm{b}}, \mathrm{G}^{\mathrm{R} A J K U M A R^{\mathrm{b}}, \mathrm{M} \mathrm{SRINIVASU}^{\mathrm{b}} \text { and P YELLA REDDY }}{ }^{\mathrm{b}}$ \\ ${ }^{a}$ Inorganic and Physical Chemistry Division, Indian Institute of Chemical Technology (IICT), Uppal \\ Road, Tarnaka, Hyderabad 500 607, India \\ ${ }^{\mathrm{b}}$ Aisin Cosmos R\&D Co. Ltd, Nanomaterials Laboratory, IICT campus, Hyderabad 500 607, India \\ e-mail: chandra@iict.res.in
}

MS received 21 July 2010; revised 2 November 2010; accepted 9 November 2010

\begin{abstract}
Heteroleptic ruthenium(II) bipyridyl complex, cis-Ru(II)(4,4'-bis(4-tert-butylstyryl)-2,2'-bipyridyl) (4,4'-dicarboxy-2,2'-bipyridyl) $\left(\mathrm{NCS}_{2}\right)$ (H112) was synthesized and characterized by ${ }^{1} \mathrm{H}-\mathrm{NMR}$, MASS, Spectrofluorometer and UV-Vis spectroscopes. The photo-voltaic performance of the sensitizer was evaluated in Dye Sensitized Solar Cell (DSSC) under irradiation of AM $1.5 \mathrm{G}$ solar light and the photovoltaic characteristics were compared with those of reference cells of HRS1 and N719 fabricated under comparable conditions. Compared to N719, H112 sensitizer showed enhanced molar extinction coefficient and relatively better monochromatic incident photon-to-current conversion efficiency (IPCE) across the spectral range of 400 to $800 \mathrm{~nm}$ with solar energy-to-electrical conversion efficiency $(\eta)$ of $2.43 \%$ [open circuit photovoltage $\left(\boldsymbol{V}_{\mathrm{OC}}\right)=0.631 \mathrm{~V}$, short-circuit photocurrent density $\left(\boldsymbol{J}_{\mathrm{SC}}\right)=8.96 \mathrm{~mA} / \mathrm{cm}^{2}$, fill factor $\left.(\mathrm{ff})=0.430\right]$, while $\eta$ values of $2.51 \%\left(\boldsymbol{V}_{\mathrm{OC}}=0.651 \mathrm{~V}, \boldsymbol{J}_{\mathrm{SC}}=9.41 \mathrm{~mA} / \mathrm{cm}^{2}, \quad \mathrm{ff}=0.410\right)$ and $2.74 \%\left(\boldsymbol{V}_{\mathrm{OC}}=0.705 \mathrm{~V}\right.$, $\left.\boldsymbol{J}_{\mathrm{SC}}=8.62 \mathrm{~mA} / \mathrm{cm}^{2}, \mathrm{ff}=0.455\right)$ were obtained for HRS1 and N719 sensitized solar cells respectively. The introduction of 4,4'-bis(4-tert-butylstyryl) moieties on one of the bipyridine moieties of $\mathbf{N} 719$ complex shows higher light absorption abilities, IPCE and $\boldsymbol{J}_{\mathrm{SC}}$.
\end{abstract}

Keywords. $\quad \mathrm{Ru}(\mathrm{II})$ complexes; extended $\pi$-conjugation; 4-tert-butylstyryl; nanocrystalline $\mathrm{TiO}_{2}$; dye sensitized solar cell.

\section{Introduction}

To replace fast depleting fossil fuels arising from increasing global energy demands the search for clean alternate energy sources is much needed. ${ }^{1-9}$ The conversion of solar light can be considered as the important renewable energy source that can be tapped for the generation of mass energy. However, the unviable production of solar panels from expensive traditional inorganic semiconductors necessitated the search for alternative cheaper solar energy technologies. ${ }^{10}$ In this context, since Michael Gratzel introduced high surface area nanoporous $\mathrm{TiO}_{2}$ films as wide band gap semiconductor, a breakthrough in the area of DSSC, the photovoltaic application of DSSC has been enormously explored because of their low

$\overline{\text { *For correspondence }}$ cost and impressive conversion efficiencies. ${ }^{11}$ In DSSC, sensitizers serve as solar light harvesters and their electronic properties influence the light harvesting efficiency and the overall photoelectric conversion efficiency. The ideal sensitizer for DSSC should have high molar extinction coefficient and absorb solar radiation strongly with absorption bands preferably covering a broad range of wavelengths across visible to near IR regions. In addition, the sensitizer should anchor strongly on semiconductor oxide (nanocrystalline $\mathrm{TiO}_{2}$ ) surface, to have good electronic communication and inject electrons efficiently into conduction band of $\mathrm{TiO}_{2}$.

N719 sensitizer in conjunction with nanocrystalline $\mathrm{TiO}_{2}$ film and $\mathrm{I}_{3}{ }^{-} / \mathrm{I}^{-}$redox couple based electrolyte give solar energy-to-electrical conversion efficiency $(\eta)$ of $10 \%$ at AM 1.5 solar radiation. ${ }^{12}$ Although Z907 sensitized solar cell resulted in low efficiency 
of around $7 \cdot 3 \%$ better stability and long-term durability in DSSC was achieved with quasi-solid state ionic liquid electrolytes. ${ }^{13}$ The sensitizer showed decreased molar extinction coefficient $(\varepsilon)$ as compared to $\mathbf{N} 719$, but the improved durability was assigned to the presence of hydrophobic long alkyl chains that increase the stability and compatibility of the dye inhibiting traces of moisture to attack NCS groups. ${ }^{13-14}$ Substituted bipyridines recently attracted special attention for their importance in biological applications as $\mathrm{Zn}^{2+}$ specific fluorescent molecular probes. ${ }^{15-17}$ Ruthenium(II) complexes with extensive modifications at 4,4'-positions of one of the two bipyridyl moieties with hydrophilic and hydrophobic substituted phenylenevinylene and thienylenevinylene as extended $\pi$-conjugations have been studied for DSSC applications. ${ }^{18-24}$ These variations in dye structure not only improved molar extinction coefficient, but also showed high stability to thermal stress, light soaking and compatibility with ionic liquid electrolytes that is attributed to the hydrophobic nature of these ligands. In addition, recent reports indicate that changes like insertion of sulfur, replacing the heteroatom with other elements of the same group and change in alkyl position effect the energy levels and electronic transitions of ruthenium(II) complexes influencing the overall performance of DSSCs. ${ }^{25-29}$ The need to develop high molar extinction coefficient sensitizers gained significant interest particularly when organic hole transport materials, with limited charge-carrier mobility are used in order to explore thin film solid state/semisolid state DSSCs. ${ }^{19,20,22,23,30-33}$

We have been engaged in our laboratory for the synthesis and evaluation of stable and efficient new metal free organic, phthalocyanine as well as ruthenium-based dyes as sensitizers for DSSC application. ${ }^{29,34-36}$ In this endeavour, the photo-voltaic performance of HRD1 and HRD2 heteroleptic ruthenium(II) bipyridyl sensitizers developed in our laboratory were found to be encouraging and comparable with that of K77 sensitizer. In an effort to develop new extended $\pi$-conjugated $\mathrm{Ru}(\mathrm{II})$ complex, H112, was designed with 4,4'-bis(4-tert-butylstyryl)-2,2'-bipyridine ancillary ligand and synthesized by HornerEmmons-Wadsworth reaction of 4-tert-butylbenzaldehyde with tetraethyl 2,2'-bipyridine-4,4'-diyldiphosphonate (scheme 1). In this paper, we present the synthesis and the photovoltaic performance of the sensitizer and the results are compared with that of HRS1 and N719 sensitizers.

\section{Experimental}

\subsection{General}

4-hexyl-thiophene-2-carboxaldehyde, 4-tert-butylbenzaldehyde, tetrabutyl-ammoniumhydroxide (TBAOH), 2,4dimethyl-3-propyl-1 H-imidazol-3-ium iodide (DMPII), 4-tert-butyl-pyridine (TBP) and titaniumtetraisopropoxide were procured from Sigma-Aldrich. The other chemicals, unless specified, are of analytical grade and used without further purification. 4,4'-Diethyl-2,2'bipyridine was procured from Merck and dichloro ( $p$ cymene) ruthenium(II) dimer was synthesized according to the reported procedures. ${ }^{37}$ Sephadex LH-20 was procured from GE Healthcare Bio-Sciences AB, SE75184, Uppsala. A fluorine-doped $\mathrm{SnO}_{2}$ conducting glass (FTO, $10 \Omega^{-1}$, Nippon Sheet Glass) was employed as substrate to coat nanocrystalline $\mathrm{TiO}_{2}$ pastes, 18 NRT and PST-400C, which were procured from JGC Catalysis and Chemicals Ltd, Japan. A $50 \mu \mathrm{m}$ thickness Surlyn tape, procured from DyeSol, 3 Dominion Place, Queanbeyan NSW, Australia was employed as gasket to seal both the working and counter electrodes. Brucker 300 Avance ${ }^{1} \mathrm{H}$ NMR spectrometer $(300 \mathrm{MHz})$ was employed to record the ${ }^{1}$ H-NMR spectra. Shimadzu LCMS-2010EV model with ESI probe was employed to record mass spectrum. The electronic absorption and emission spectra of the complex were recorded in N,Ndimethyl-formamide (DMF) using Shimadzu UV-Vis spectrometer, model 1700 and Fluorolog 3, J.Y.Horiba Fluorescence Spectrometer respectively.

\subsection{Experimental procedures}

2.2a 2, 2'-Bipyridine-4, 4'-dicarboxylic acid (dcbpy): 4, 4'-Dimethyl-2, 2'-bipyridine $(1.0 \mathrm{~g}, 5.43 \mathrm{mmol})$ was dissolved in con. $\mathrm{H}_{2} \mathrm{SO}_{4}(30 \mathrm{ml})$ at room temperature. To this solution, $\mathrm{K}_{2} \mathrm{Cr}_{2} \mathrm{O}_{7}(6 \cdot 2 \mathrm{~g})$ was added in portions during $4 \mathrm{~h}$. The reaction flask was heated to $80^{\circ} \mathrm{C}$ for $12 \mathrm{~h}$ with stirring. After cooling to room temperature, the reaction mixture was poured into ice water $(200 \mathrm{ml})$. After keeping it for $12 \mathrm{~h}$ at $0^{\circ} \mathrm{C}$, the suspension was filtered by suction. The greenish-yellow precipitate separated was washed thoroughly with distilled water (until the filtrate is colourless) and dried under vacuum. The pale yellow solid was suspended in $\mathrm{HNO}_{3}(50 \%$, $18 \mathrm{ml}$ ) and refluxed for $8 \mathrm{~h}$. After cooling to room temperature, the reaction mixture was poured into ice water $(180 \mathrm{ml})$ and stored at $0^{\circ} \mathrm{C}$ overnight. The white solid obtained was collected on a sintered glass crucible (G4), washed thoroughly with water until the filtrate is 


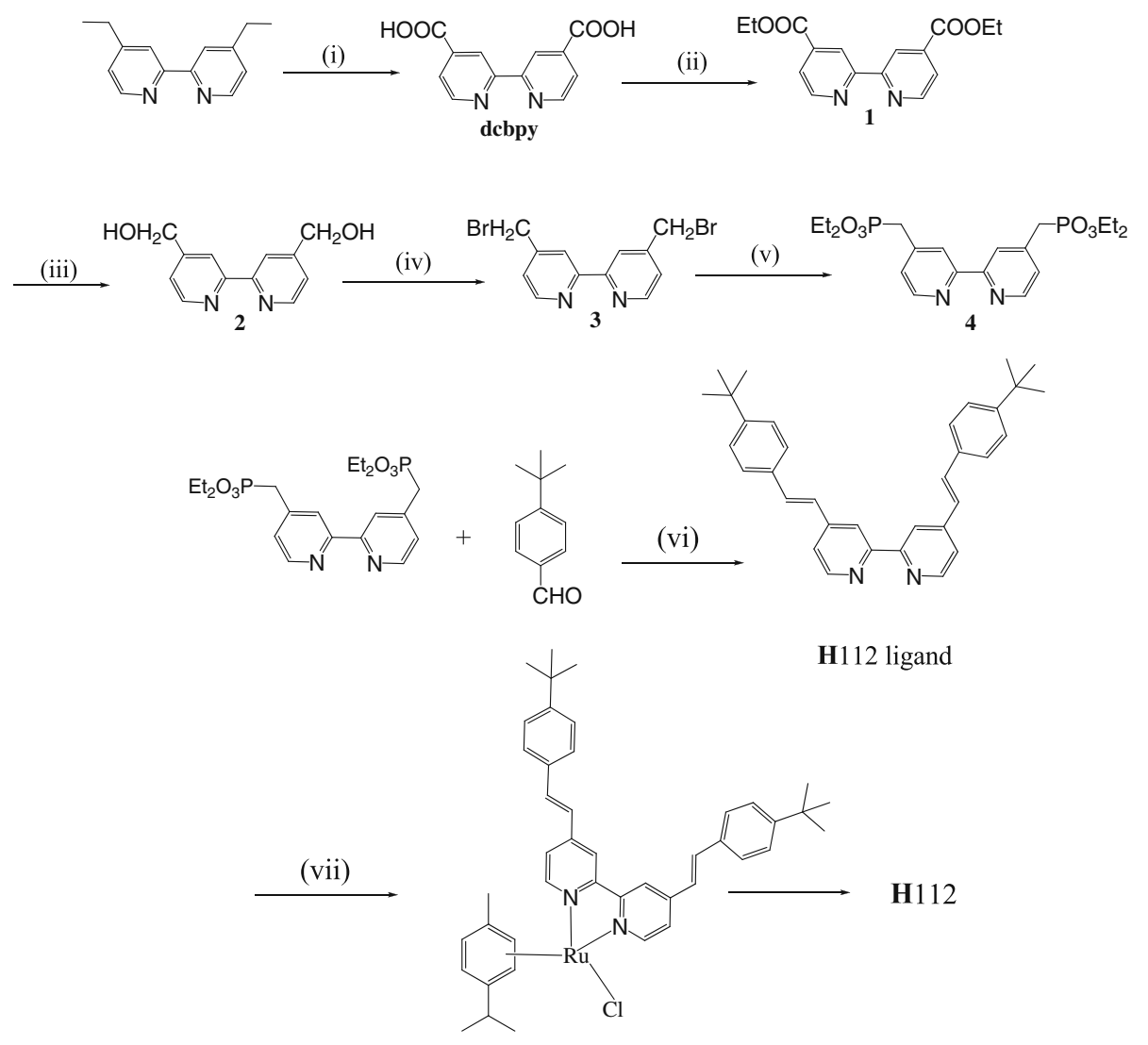

Scheme 1. Synthesis route for H112 sensitizer.

colourless and dried under vacuum to give 2,2' bipyridine $-4,4$ ' dicarboxylic acid $(1 \cdot 12 \mathrm{~g}$, yield $85 \%)$ as a white solid compound. ${ }^{1} \mathrm{H}-\mathrm{NMR}\left(\mathrm{D}_{2} \mathrm{O} / \mathrm{NaOD}\right) \mathrm{ppm}$ : $7 \cdot 72(2 \mathrm{H}, \mathrm{dd}), 8 \cdot 22(2 \mathrm{H}, \mathrm{s}), 8 \cdot 62(2 \mathrm{H}, \mathrm{d})$. ESI-MASS $\left(\mathrm{C}_{12} \mathrm{H}_{8} \mathrm{~N}_{2} \mathrm{O}_{4}\right)$ calculated 244, found 244.

2.2b 4, 4'-Di(ethoxycarbonyl)-2, 2'-bipyridine (1): To a suspension of $4,4^{\prime}$ 'dicarboxy-2,2'-bipyridine $(5 \cdot 0 \mathrm{~g}$, $20.5 \mathrm{mmol})$ in absolute ethanol $(400 \mathrm{ml})$ was added to concentrated sulfuric acid $(5 \mathrm{ml})$. The mixture was refluxed for $4 \mathrm{~h}$ to obtain a clear solution and then cooled to room temperature. Water $(400 \mathrm{ml})$ was added and the excess ethanol removed under vacuum. The $\mathrm{pH}$ was adjusted to neutral with $\mathrm{NaOH}$ solution, and the resulting precipitate was filtered and washed with water $(\mathrm{pH}=7 \cdot 0)$. The solid was dried to obtain $(5 \cdot 5 \mathrm{~g}$, yield $90 \%) .{ }^{1} \mathrm{H}$ NMR $\left(\mathrm{CDCl}_{3}, \delta\right): 3.95\left(3 \mathrm{H}, \mathrm{s}, \mathrm{CH}_{3}\right)$; $4.05\left(3 \mathrm{H}, \mathrm{s}, \mathrm{CH}_{3}\right) ; 7.98(2 \mathrm{H}, \mathrm{d}, J=6 \mathrm{~Hz}$, aryl $\mathrm{H}$ on $\mathrm{C} 5$ and $\mathrm{C}^{\prime}$ ) $; 8.88\left(2 \mathrm{H}, \mathrm{d}, J=6 \mathrm{~Hz}\right.$, aryl $\mathrm{H}$ on $\mathrm{C}^{\prime}$ and $\mathrm{C}^{\prime}$ '); $9 \cdot 00\left(2 \mathrm{H}, \mathrm{s}\right.$, aryl $\mathrm{H}$ on $\mathrm{C} 3$ and $\left.\mathrm{C} 3{ }^{\prime}\right)$. ESI-MASS $\left(\mathrm{C}_{16} \mathrm{H}_{16} \mathrm{~N}_{2} \mathrm{O}_{4}\right)$ calculated 300 , found 300 .

2.2c 4, 4'-Bis(hydroxymethyl)-2, 2'-bipyridine (2): Sodium borohydride $(8.2 \mathrm{~g}, 0.215 \mathrm{mmol})$ was added in one portion to a suspension of $1(3.0 \mathrm{~g}, 10.0 \mathrm{mmol})$ in absolute ethanol $(200 \mathrm{ml})$. The mixture was refluxed for $3 \mathrm{~h}$ and cooled to room temperature, and then saturated ammonium chloride $(200 \mathrm{ml})$ solution was added to decompose the excess borohydride. Ethanol was removed under vacuum and the precipitate dissolved in minimum quantity of water. The resulting solution was extracted with ethyl acetate $(5 \times 200 \mathrm{ml})$ and dried over sodium sulfate $(1.74 \mathrm{~g}$, yield $81 \%)$. ${ }^{1} \mathrm{H}$ NMR $\left(\mathrm{CD}_{3} \mathrm{OD}, \ddot{a}\right): 4.75\left(4 \mathrm{H}, \mathrm{s}, \mathrm{CH}_{2}\right) ; 7 \cdot 43(2 \mathrm{H}, \mathrm{d}$, $J=5.5 \mathrm{~Hz}$, aryl $\mathrm{H}$ on $\mathrm{C} 5$ and $\mathrm{C} 5) ; 8.21(2 \mathrm{H}$, s, aryl $\mathrm{H}$ on $\mathrm{C} 3$ and $\left.\mathrm{C}^{\prime}\right) ; 8.59(2 \mathrm{H}, \mathrm{d}, J=5.5 \mathrm{~Hz}$, aryl $\mathrm{H}$ on $\mathrm{C} 6$ and C6'); ESI-MASS $\left(\mathrm{C}_{12} \mathrm{H}_{12} \mathrm{~N}_{2} \mathrm{O}_{2}\right)$ calculated 216, found 216 .

2.2d 4, 4'- Bis(bromomethyl) - 2, 2'-bipyridine (3): 4,4'-Bis(hydroxy methyl)- 2, 2'- bipyridine $(90 \cdot 0 \mathrm{~g}$, $4.2 \mathrm{mmol})$ was dissolved in a mixture of $48 \% \mathrm{HBr}(20$ $\mathrm{ml})$ and concentrated sulfuric acid $(6.7 \mathrm{ml})$. The resulting solution was refluxed for $6 \mathrm{~h}$ and then allowed to cool to room temperature, and water $(40 \mathrm{ml})$ was added. The $\mathrm{pH}$ was adjusted to neutral with $\mathrm{NaOH}$ solution and the resulting precipitate was filtered, washed with water $(\mathrm{pH}=7 \cdot 0)$, and air-dried. The 
product was dissolved in chloroform $(40 \mathrm{ml})$ and filtered. The solution was dried over magnesium sulfate and evaporated to dryness, yielding a white powder of $(1 \cdot 2 \mathrm{~g}$, yield $85 \%) .{ }^{1} \mathrm{H}$ NMR $\left(\mathrm{CDCl}_{3}, \delta\right): 4.50(4 \mathrm{H}, \mathrm{s}$, $\left.\mathrm{CH}_{2}\right) ; 7 \cdot 38\left(2 \mathrm{H}, \mathrm{d}, J=5 \mathrm{~Hz}\right.$, aryl $\mathrm{H}$ on $\mathrm{C} 5$ and $\left.\mathrm{C}^{\prime}\right)$; $8.45(2 \mathrm{H}, \mathrm{s}$, aryl $\mathrm{H}$ on $\mathrm{C} 3$ and $\mathrm{C} 3$ '); $8.68(2 \mathrm{H}, \mathrm{d}, J=5$ $\mathrm{Hz}$, aryl $\mathrm{H}$ on $\mathrm{C} 6$ and $\left.\mathrm{C} 6{ }^{\prime}\right)$. ESI-MASS $\left(\mathrm{C}_{12} \mathrm{H}_{10} \mathrm{Br}_{2} \mathrm{~N}_{2}\right)$ calculated 339, found 339 .

2.2e 4, 4'-Bis(diethylmethylphosphonate)-2, 2'-bipyridine (4): A chloroform (10 ml) solution of $3(1.5 \mathrm{~g}$, $4.4 \mathrm{mmol})$ and triethyl phosphite $(15 \mathrm{ml})$ was refluxed for $3 \mathrm{~h}$ under nitrogen. The excess phosphite was removed under high vacuum, and then the crude mass was purified by column chromatography on silica gel using ethyl acetate/methanol (80/20) as eluent $(1.6 \mathrm{~g}$, yield $80 \%) .{ }^{1} \mathrm{H}$ NMR $\left(\mathrm{CDCl}_{3}, \delta\right): 1.23(12 \mathrm{H}, \mathrm{t}$, $\left.J=7 \mathrm{~Hz}, \mathrm{CH}_{3}\right) ; 3 \cdot 20\left(4 \mathrm{H}, \mathrm{d}, J=22 \mathrm{~Hz}, \mathrm{CH}_{2} \mathrm{P}\right) ; 4.05(8$ $\mathrm{H}$, apparent quintet, $\left.J=7 \mathrm{~Hz}, \mathrm{OCH}_{2}\right) ; 7 \cdot 25-7 \cdot 35(2 \mathrm{H}$, $\mathrm{m}$, aryl $\mathrm{H}$ on $\mathrm{C} 5$ and $\left.\mathrm{C}^{\prime}\right) ; 8 \cdot 34-8 \cdot 37(2 \mathrm{H}, \mathrm{m}$, aryl $\mathrm{H}$ on $\mathrm{C} 3$ and $\left.\mathrm{C} 3{ }^{\prime}\right) ; 8.62(2 \mathrm{H}, \mathrm{d}, J=5 \mathrm{~Hz}$, aryl $\mathrm{H}$ on $\mathrm{C} 6$ and C6'). ESI-MASS $\left(\mathrm{C}_{20} \mathrm{H}_{30} \mathrm{~N}_{2} \mathrm{O}_{6} \mathrm{P}_{2}\right)$ calculated 456 , found 456.

$2.2 \mathrm{f}$ 4,4'-Bis(4-tert-butylstyryl)-2,2'-bipyridyl (H112 ligand): Sodium hydride $(171 \mathrm{mg}, 7 \cdot 12 \mathrm{mmol})$ was washed (3 times) with dry hexane and THF $(40 \mathrm{ml})$ was added. To this suspension, a THF solution of $\mathbf{4}$ (408 $\mathrm{mg}, 0.89 \mathrm{mmol}$ ) was added and the resulting mixture was stirred at room temperature for 30 minutes. Then 4-tert-butlbenzaldehyde $(2.49 \mathrm{mmol})$ dissolved in THF was added drop-wise at room temperature while stirring. The reaction mixture was refluxed for $12 \mathrm{~h}$. After cooling to room temperature, the mixture was filtered through a short plug of silica gel using diethyl ether or dichloromethane. The filtrate was concentrated and methanol was added. The product was precipitated, filtered and washed with cool methanol. The solid was dried to obtain the product (231 mg 55\%). ${ }^{1} \mathrm{H}-\mathrm{NMR}$ (L2): $8 \cdot 68(\mathrm{~d}, 1 \mathrm{H})$, $8 \cdot 52(\mathrm{~s}, 1 \mathrm{H}), 7 \cdot 53(\mathrm{~d}, 1 \mathrm{H}), 7 \cdot 51(\mathrm{~s}, 2 \mathrm{H}), 7 \cdot 46-7 \cdot 37(\mathrm{~m}, 3 \mathrm{H})$, $7 \cdot 10(\mathrm{~d}, 1 \mathrm{H}), 1 \cdot 34(\mathrm{~s}, 9 \mathrm{H})$; ESI-MASS $\left(\mathrm{C}_{34} \mathrm{H}_{36} \mathrm{~N}_{2}\right)$ calculated 472 , found 472 .

2.2gH112 Complex: 4,4'-bis(4-tert-butylstyryl)-2,2'bipyridyl $(180 \mathrm{mg}, 0.38 \mathrm{mmol})$ and dichloro ( $p$-cymene) ruthenium(II) dimer (116 mg, $0.19 \mathrm{mmol})$ in DMF were heated at $60^{\circ} \mathrm{C}$ for a period of $4 \mathrm{~h}$ under nitrogen in the dark. Subsequently, 4, 4'-dicarboxylic acid-2, 2'bipyridine $(92.7 \mathrm{mg}, 0.38 \mathrm{mmol})$ was added and the reaction mixture was heated to $140^{\circ} \mathrm{C}$ for another 4h. To the resulting dark green solution solid $\mathrm{NH}_{4} \mathrm{NCS}(867 \mathrm{mg}, 11.4 \mathrm{mmol}$ ) was added and the reaction mixture was further heated for $4 \mathrm{~h}$ at $140^{\circ} \mathrm{C}$. DMF was removed on a rotavapor under vacuum and water $(220 \mathrm{ml})$ was added to get the precipitate. The purple solid was filtered off, washed with water and ether, and dried under vacuum. The crude masses were dissolved in basic methanol (with TBAOH) and further purified on the Sephadex LH-20 with methanol as eluent. The main band was collected, concentrated, and precipitated with acidic methanol $\left(\mathrm{HNO}_{3}\right)$. This purification was repeated two times to obtain pure $\mathbf{H} 112$ (350 mg, yield 65\%).

${ }^{1} \mathrm{H}-\mathrm{NMR}\left(300 \mathrm{MHz}, 25^{\circ} \mathrm{C}, \mathrm{CD}_{3} \mathrm{OD}+\mathrm{CDCl}_{3}\right) \delta[\mathrm{ppm}]$ : $9 \cdot 49(\mathrm{~d}, 1 \mathrm{H}), 9.33(\mathrm{~d}, 1 \mathrm{H}), 8.95(\mathrm{~d}, 1 \mathrm{H}), 8.38(\mathrm{~s}, 1 \mathrm{H})$, $8 \cdot 22(\mathrm{~s}, 1 \mathrm{H}), 8 \cdot 05(\mathrm{~s}, 1 \mathrm{H}), 7 \cdot 72-7.40(\mathrm{~m}, 2 \mathrm{H}), 7 \cdot 32$ $7 \cdot 15(\mathrm{~m}, 2 \mathrm{H}), 7 \cdot 10-6 \cdot 91(\mathrm{~m}, 2 \mathrm{H}), 3.91(\mathrm{~m}, 16 \mathrm{H}), 1 \cdot 66$ $(\mathrm{m}, 16 \mathrm{H}), 1 \cdot 52-1 \cdot 17(\mathrm{~m}, 25 \mathrm{H}), 1 \cdot 0(\mathrm{t}, 24 \mathrm{H})$. ESI-MS: $\mathrm{RuC}_{48} \mathrm{H}_{44} \mathrm{~N}_{6} \mathrm{O}_{4} \mathrm{~S}_{2}\left(\mathrm{C}_{16} \mathrm{H}_{36} \mathrm{~N}\right)^{2}$ calculated 1418, found 1418.

\subsection{Preparation of nanocrystalline $\mathrm{TiO}_{2}$ dye sensitized electrode}

A compact layer was formed over $2 \times 2 \mathrm{~cm}^{2}$ FTO glass by spin coating of a solution of $0.5 \mathrm{M}$ Ti(isopropoxide) $)_{4}$ and $0.6 \mathrm{M} \mathrm{HCl}$ prepared using $98 \%$ absolute ethanol. The glass plates were then kept in the preheated oven at $100^{\circ} \mathrm{C}$ for 15 minutes. One film of 18 NRT with an active area of $7 \times 10.5 \mathrm{~mm}^{2}$ was formed on the glass plate using screen printing technique and then heated in pre-heated oven at $100^{\circ} \mathrm{C}$ for 30 minutes. After that another film of 18 NRT was formed over the $1^{\text {st }}$ film and then heated in the pre-heated oven at $100^{\circ} \mathrm{C}$ for 30 minutes. Then a film of scattering layer was formed with PST-400C and then annealed in air for $1 \mathrm{~h}$ at $500^{\circ} \mathrm{C}$ to give overall thicknesses of $9 \mu \mathrm{m}$. The films were cooled to around $100^{\circ} \mathrm{C}$ and sensitized by immersing the $\mathrm{TiO}_{2}$ electrodes in dye solution for $16 \mathrm{~h}$ at room temperature under dark. The counter electrode was prepared by spin coating platinic solution on fluorine-doped tin oxide glass. Spin coater (Model WS-400B-6NPP/LITE), from Laurell Technologies Corporation was employed to coat hexachloroplatinic acid/isopropanol (1/4) over FTO glass plate. In order to determine dye loadings, the dye sensitized photo-electrodes were immersed in $0.3 \mathrm{M} \mathrm{KOH}$ methanol solution to desorb the dye molecules. The quantity of desorbed dye in the alkaline solution was established by UV/Vis spectroscopy in a separate series of experiments. 


\subsection{DSSC Assembling}

DSSCs were fabricated following the procedures described in the literature. ${ }^{38-40}$ A $50 \mu \mathrm{m}$ thickness surlyn was sandwiched between the counter electrode and dye sensitized $\mathrm{TiO}_{2}$ electrode. The assembly was then placed on a preheated hot plate where the top counter electrode was pressed gently to seal both electrodes. The iodide electrolyte solution was filled through the predrilled hole present on the counter electrode and drawn into the space between the electrodes by capillary action. Then the hole was sealed using surlyn tape. The DSSCs thus fabricated in our laboratory have an active area of $0.74 \mathrm{~cm}^{2}$, which is around 6 times higher than the regular test cells of active area of $0.16 \mathrm{~cm}^{2}$. Two electrolytes E6 and Ei301 were employed to evaluate the performance of H112 sensitizer. E6 electrolyte is composed of DMPII $(0.6 \mathrm{M}), \mathrm{I}_{2}(0.1 \mathrm{M})$ LiI $(0.5 \mathrm{M})$ and TBP $(0.5 \mathrm{M})$ in methoxypropionitrile, while Ei301 was prepared from LiI $(1 \cdot 0 \mathrm{M})$ and $\mathrm{I}_{2}(0 \cdot 05 \mathrm{M})$ in $\gamma$-butyrolactone.

\subsection{Characterization and measurements}

Incident photon-to-current conversion efficiency spectra were measured using illumination from a $150 \mathrm{~W}$ Xe lamp/grating monochromator calibrated ithilicon photodiode (traceable (5\% to NBS). The current-voltage characteristics of the cells were measured using a xenon arc solar simulator (ELLSOL 1000, model SVX 1450) with an AM 1.5 spectral filter, and the intensity was adjusted to provide 1 sun $\left(100 \mathrm{~mW} \mathrm{~cm}\right.$ cm $\left.^{-2}\right)$ using a calibrated GaAs solar cell. Based on $\boldsymbol{I}-\boldsymbol{V}$ curve, the fill factor (ff) is defined as $\mathrm{ff}=\left(\begin{array}{lll}\boldsymbol{I}_{\max } & \mathrm{x} & \boldsymbol{V}_{\max }\end{array}\right) /\left(\begin{array}{lll}\boldsymbol{I}_{S C} & \mathrm{x} & \boldsymbol{V}_{\mathrm{OC}}\end{array}\right)$, where $\boldsymbol{I}_{\max }$ and $\boldsymbol{V}_{\max }$ are photocurrent and photovoltage for maximum power output $\left(\boldsymbol{P}_{\max }\right), \boldsymbol{I}_{\mathrm{SC}}$ and $\boldsymbol{V}_{\text {OC }}$ are the short-circuit photocurrent and opencircuit photovoltage, respectively. The overall energy conversion efficiency $(\boldsymbol{\eta})$ is defined as $\boldsymbol{\eta}=\left(\boldsymbol{I}_{S C} \times \boldsymbol{V}_{\mathrm{OC}} \mathrm{X}\right.$

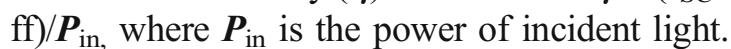

\section{Results and discussion}

\subsection{Synthesis of $\boldsymbol{H} 112$}

The structure of the new heteroleptic ruthenium(II) bipyridyl complex, cis-Ru(II)(4,4'-bis(4-tert-butylstyryl)-2,2'-bipyridyl) (4,4'-dicarboxy-2,2'-bipyridyl) $\left(\mathrm{NCS}_{2}\right)$ is shown in figure 1 The ancillary ligand 4,4'bis(4-tert-butylstyryl)-2,2'-bipyridine was prepared by Horner-Emmons-Wadsworth reaction of 4-tert-butyl- benzaldehyde with a precursor, tetraethyl 2,2'-bipyridine-4,4'-diylbis(methylene)diphosphonate, which is accomplished in 5 steps starting from 4,4'-diethyl-2,2'bipyridine (scheme 1).

Reagents: (i) $\mathrm{K}_{2} \mathrm{Cr}_{2} \mathrm{O}_{7} / \mathrm{H}_{2} \mathrm{SO}_{4}$, for $12 \mathrm{~h}$ at $80^{\circ} \mathrm{C}$ (yield$85 \%$ ). (ii) $\mathrm{EtOH}-\mathrm{H}_{2} \mathrm{SO}_{4}$, reflux for $4 \mathrm{~h}$ (yield-90\%). (iii) $\mathrm{NaBH}_{4}-\mathrm{EtOH}$, reflux for $3 \mathrm{~h}$ (yield-81\%). (iv) $\mathrm{HBr}$ $\mathrm{H}_{2} \mathrm{SO}_{4}$, reflux for $6 \mathrm{~h}$ (yield-85\%). (v) $\mathrm{P}(\mathrm{OEt})_{3}-\mathrm{CHCl}_{3}$, reflux for $3 \mathrm{~h}$ (yield-80\%). (vi) $\mathrm{NaH}-\mathrm{THF}$, reflux for 12 h (yield-55\%). (vii) Ru-p-cymene complex, 2,2'-bipyridine-4,4'-dicarboxylic acid, $\mathrm{NH}_{4} \mathrm{NCS}$, DMF, reflux for $12 \mathrm{~h}$ (yield-65\%).

The $\mathbf{H} 112$ complex was obtained from the reaction of $\left[\mathrm{RuCl}_{2} p \text {-cymene }\right]_{2}$ and the 4,4'-bis(4-tert-butylstyryl)2,2'-bipyridine followed by addition of 2,2'-bipyridine4,4'-dicarboxylic acid and excess ammonium thiocyanate. The dried crude complex was purified on Sephadex LH20 column chromatography to afford the ruthenium complex. The presence of a peak at 1418 in ESI-MASS spectrum corresponds to molecular ion peak of H112 with 2 TBA. The reference sensitizers HRS1 and N719 were synthesized in accordance with the procedures reported. $^{12,21}$ The FTIR spectrum of H112 was compared with that of $\mathbf{N} 719$ (figure S1 [Electronic supporting information]). The bands at around $2100 \mathrm{~cm}^{-1}$ in FTIR spectrum of $\mathbf{H 1 1 2}$ complex corresponds to the NCS stretching band indicating that NCS coordinated to the center ruthenium through $\mathrm{N}$-atom. The stretching bands at around 1610 and $1357 \mathrm{~cm}^{-1}$ are due to the symmetric and asymmetric stretching modes of corbaxylate groups. The stretching bands at around 2961 to $2865 \mathrm{~cm}^{-1}$ correspond to the aryl-tert-butyl groups of H112 sensitizer. The absorption bands at 1540 and 1463 $\mathrm{cm}^{-1}$ are ascribed to bipyridyl modes, while the larger broad stretching band centered at $3397 \mathrm{~cm}^{-1}$ is due to the adsorbed moisture of the dye.

\subsection{Electronic absorption, emission and redox properties}

The absorbance of 4,4'-bis(4-tert-butylstyryl)-2,2'bipyridine (H112 ligand) $(0 \cdot 1 \mathrm{mM})$ was recorded in ethanol and compared with that of 4,4'-bis((E)-2-(5hexylthiophen-2-yl)vinyl)-2,2'-bipyridine (HRS1 ligand) (figure S2a, ESI). The absorption spectrum of H112 was recorded in DMF as a function of wavelength and the spectrum was compared with those of HRS1 and N719 sensitizers (figure S2b, ESI).

The absorption bands at 326 and $355 \mathrm{~nm}$ corresponds to $\pi \rightarrow \pi^{*}$ of ligands of H112 and HRS1 (figure S2a ESI). The red shift absorption of 4,4'-bis((E)-2-(5hexylthiophen-2-yl)vinyl)-2,2'-bipyridine by $29 \mathrm{~nm}$ 


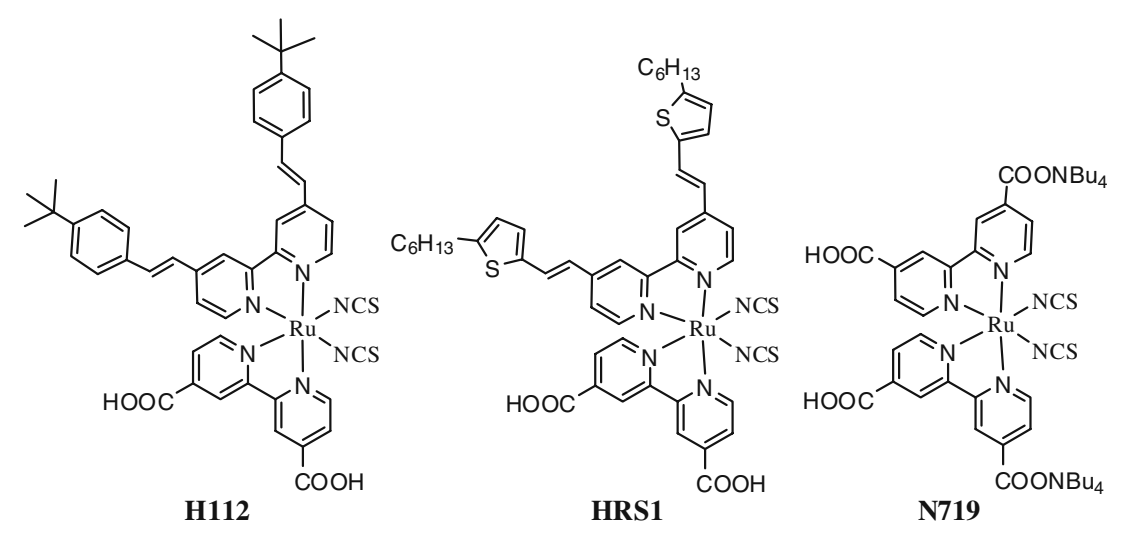

Figure 1. Structures of the new heteroleptic polypyridyl ruthenium(II) complex H112 and reference sensitizers HRS1, N719.

along with the enhanced molar absorptivity could be due to the increase of conjugation further by two double bonds bridged with sulfur atom in thiophene moiety with pyridine moieties. H112 complex shows one metal to ligand charge transfer transitions (MLCT) absorption band in long wavelength region, while a relatively weak shoulder MLCT band was observed in short wavelength region (figure S2b ESI). Compared to N719, H112 with (E)-4-(4-tert-butylstyryl) as $\pi$-conjugation extension on one of the bipyridine moieties of $\mathbf{N 7 1 9}$ have improved molar extinction coefficients, indicating higher light harvesting ability. The $\varepsilon$-values and absorption maxima of low energy absorption band of $\mathbf{H} 112$ measured in DMF are $16,700 \mathrm{~cm}^{-1} \mathrm{M}^{-1}$ (at $532 \mathrm{~nm}$ ), while HRS1 showed high $\varepsilon$-value of $18,300 \mathrm{~cm}^{-1} \mathrm{M}^{-1}$ at $536 \mathrm{~nm}$. The $\mathbf{H} 112$ sensitizer showed better sensitivity across the spectral range of $400-800 \mathrm{~nm}$ as compared to $\mathbf{N} 719$ ( $\varepsilon$ value of $13,200 \mathrm{M}^{-1} \mathrm{~cm}^{-1}$ ) under similar measuring conditions.

The enhanced molar extinction coefficient of high energy absorption band of $\mathbf{H} 112$ could be due to the contribution of $\pi-\pi^{*}$ transition of 4,4'-bis(4-tert-butylstyryl)-2,2'-bipyridine to the corresponding metal $\rightarrow$ ligand charge transfer transition of $\mathbf{H} 112$ complex as compared to that of 4,4'-dicarboxy-2,2'-bipyridine in N719 complex. Compared to HRS1, the lower molar extinction coefficient of high energy absorption band of H112 could be due to the reduced intensity of $\pi-\pi^{*}$ transitions of 4,4'-bis(4-tert-butylstyryl)-2,2'-bipyridine ligand because of its increased HOMO/LUMO band gap compared to that of 4,4'-bis((E)-2-(5-hexylthiophen-2-yl)vinyl)-2,2'-bipyridine of HRS1.

To get an insight into the electron distribution of the highest occupied molecular orbital (HOMO) and lowest unoccupied molecular orbital (LUMO) of H112 and HRS1 ligands and the corresponding complexes, the geometries of the electronic ground states of the ligands were optimized using DFT-B3LYP method with Gaussian 09 W programme using 6-31g (d) basis function on $\mathrm{C}, \mathrm{H}, \mathrm{N}$ and $\mathrm{S}$ atoms. The HOMO-LUMO of $\mathbf{H} 112$ and HRS1 ligands are depicted in figures $2 \mathrm{a}$ and $\mathrm{b}$. The simulation studies showed higher HOMO/LUMO energy band gap for H112 ligand by $0 \cdot 31 \mathrm{eV}$ as compared to that of HRS1 ligand.

The emission spectra of HRS1 and H112 sensitizers were recorded in DMF by exciting these molecules at wavelengths of 555 and $545 \mathrm{~nm}$ respectively. The emission spectra were analysed by Gaussian Program in Origin to calculate the emission maxima for these complexes (figure S2 ESI). Electrochemical properties of $\mathbf{H} 112$ were scrutinized by cyclic voltammetry using tetra-butyl ammonium perchlorate $(0 \cdot 1 \mathrm{M}$ in acetonitrile) and ferrocene as an internal standard at $0.42 \mathrm{~V} v$ s. SCE and the cyclic voltammogram of $\mathbf{H} 112$ is shown in figure S3 (ESI). The oxidation potential obtained for $\mathbf{H} 112$ is $0.73 \mathrm{~V}$, while the reduction potential is $-0.91 \mathrm{~V} v s$. SCE. The more positive potential of the H112 sensitizer, relative to $\mathrm{I}^{-} / \mathrm{I}_{3}{ }^{-}$redox couple in the electrolyte, provide a large thermodynamic driving force for the regeneration of the dye by iodide. Based on absorption and emission spectra, the excitation transition energy $\left(E_{0-0}\right)$ of $\mathbf{H} 112$ was estimated to be $1.773 \mathrm{eV}$ and the standard potentials $\left(\phi^{0}\left(\mathrm{~S}+/ \mathrm{S}^{*}\right)\right)$ calculated from the relation of $\left[\phi^{0}(\mathrm{~S}+/ \mathrm{S})=\right.$ $\left.\phi^{0}\left(\mathrm{~S}+/ \mathrm{S}^{*}\right)-E 0-0\right]$ for this sensitizer is $-1.043 \mathrm{~V}$ versus SCE. So, $\phi^{0}\left(\mathrm{~S}+/ \mathrm{S}^{*}\right)$ value is more negative (or higher in energy) than the conduction band edge of $\mathrm{TiO}_{2}$ and providing a thermodynamic driving force to inject electron from the dye to $\mathrm{TiO}_{2}$.

The optimum conditions for colouring of these dyes on $\mathrm{TiO}_{2}$ electrode are found to be $3 \times 10^{-4} \mathrm{M}$ dye in ethanol and $16 \mathrm{~h}$ under dark. Absorption spectra of dye sensitized $\mathrm{TiO}_{2}$ electrodes with reference to identical dye free blank $\mathrm{TiO}_{2}$ electrodes used to correct the light 
(a)

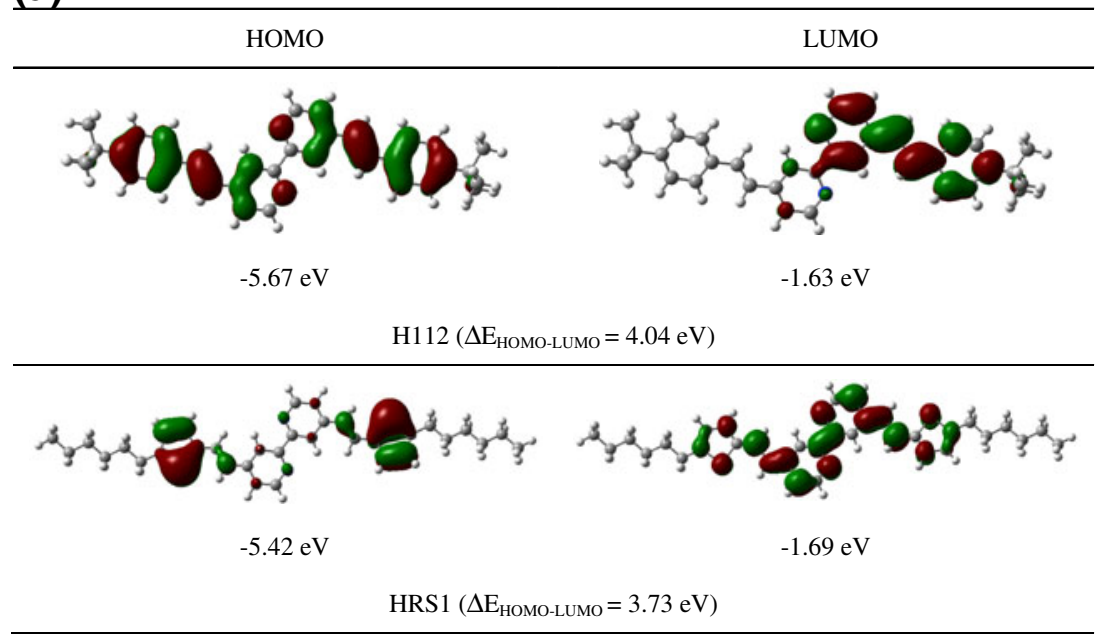

(b)

\begin{tabular}{cccc}
$\Delta \mathrm{E}_{(\text {Hомо-1)- }}$ & $\lambda_{\max }$ & \\
$($ (UUMO+1) & $(\mathrm{nm})$ & $\mathrm{F}$ \\
$(\mathrm{eVs})$ & & \\
\hline
\end{tabular}

$\mathrm{H} 112$

400690

HOMO-1 (-5.72)

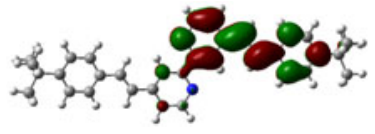

LUMO+1 (-1.62)

HRS1

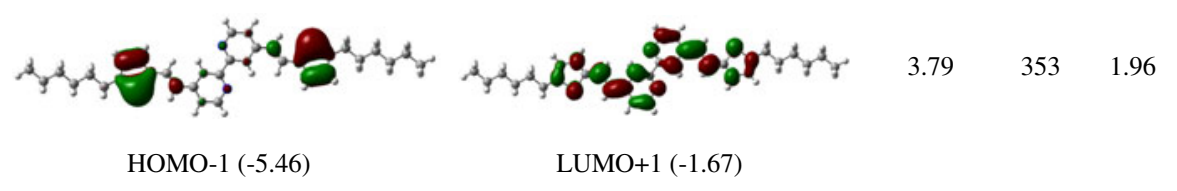

Figure 2. (a) HOMO and LUMO orbital diagrams along with the HOMO, LUMO

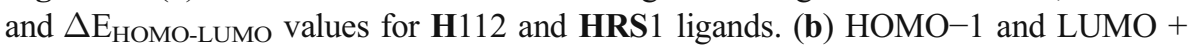
1 orbital diagrams along with the HOMO-1, LUMO $+1, \Delta \mathrm{E}_{(\mathrm{HOMO}-1)-(\mathrm{LUMO}+1)}$, $\lambda_{\max }$ and oscillatory strengths values for H112 and HRS1 ligands.

scatter phenomena were recorded. For comparison purpose, the absorption of the sensitizers are normalized with their absorption maxima of low energy absorption bands and the normalized absorptions for each sensitizer are plotted as function of wavelength (figure $\mathbf{S 4}$ and figure S5, ESI).

The absorption spectra of dye sensitized mesoporous $\mathrm{TiO}_{2}$ films shown in figure $\mathbf{S 4}$ [ESI] indicate not only the presence of dye but also the anchoring of dye on $\mathrm{TiO}_{2}$ surface. When attached on $\mathrm{TiO}_{2}$ surface, the absorption spectrum of dyes tends to shift relative to the spectrum recorded in solution. As expected, the high energy absorption bands of HRS1, H112 and
N719 sensitized $\mathrm{TiO}_{2}$ electrodes are red shifted, while their low energy absorption bands are blue shifted as compared to absorption spectrum recorded in DMF. The shift in absorption spectra on $\mathrm{TiO}_{2}$ surface is due to the fact that the carboxylate groups of the sensitizers bind electronically to the $\mathrm{TiO}_{2}$ surface. In case of HRS1, the position of low energy MLCT band maxima is slightly red shifted and broadened as compared to that of N719. The high energy MLCT bands of HRS1 and H112 sensitizers have higher sensitivity in the short wavelength region as these sensitizers contain extended $\pi$-conjugations on ancillary bipyridyl ligands. 


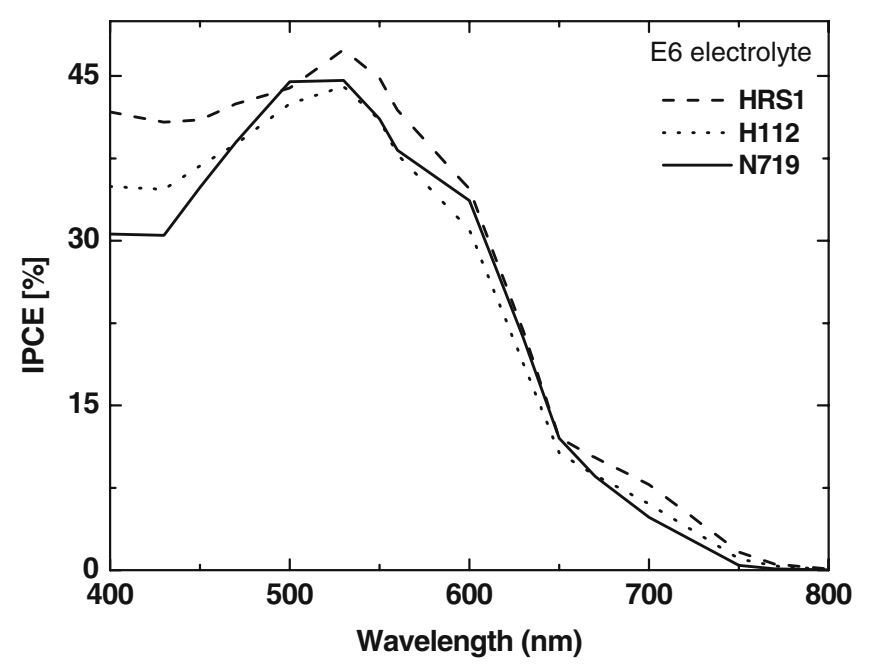

Figure 3. Photocurrent action spectra of devices fabricated from $0.74 \mathrm{~cm}^{2}$ active area $\mathrm{TiO}_{2}$ electrodes sensitized in dye solutions of ethanol and E6 electrolyte: DMPII (0.6 M), $\mathrm{I}_{2}$ $(0 \cdot 1 \mathrm{M}) \mathrm{LiI}(0 \cdot 5 \mathrm{M})$ and TBP $(0 \cdot 5 \mathrm{M})$ in methoxypropionitrile.

\subsection{Evaluation of DSC}

To evaluate the photovoltaic performance of $\mathbf{H} 112$ sensitizer in test cell, E6 electrolyte was prepared in accordance with the reported procedure keeping the redox couple concentration $\left(\left[\mathrm{I}^{-}\right]+\left[\mathrm{I}_{3}^{-}\right]\right)$as 1.5 and the ratio $\left(\left[\mathrm{I}^{-}\right] /\left[\mathrm{I}_{2}\right]\right)$ as $4 / 1 .^{41}$ The short-circuit photocurrent plotted as function of redox couple concentration showed maximum $\boldsymbol{J}_{\mathbf{S C}}$ with the above electrolyte. Figure 3 shows the action spectra of monochromatic

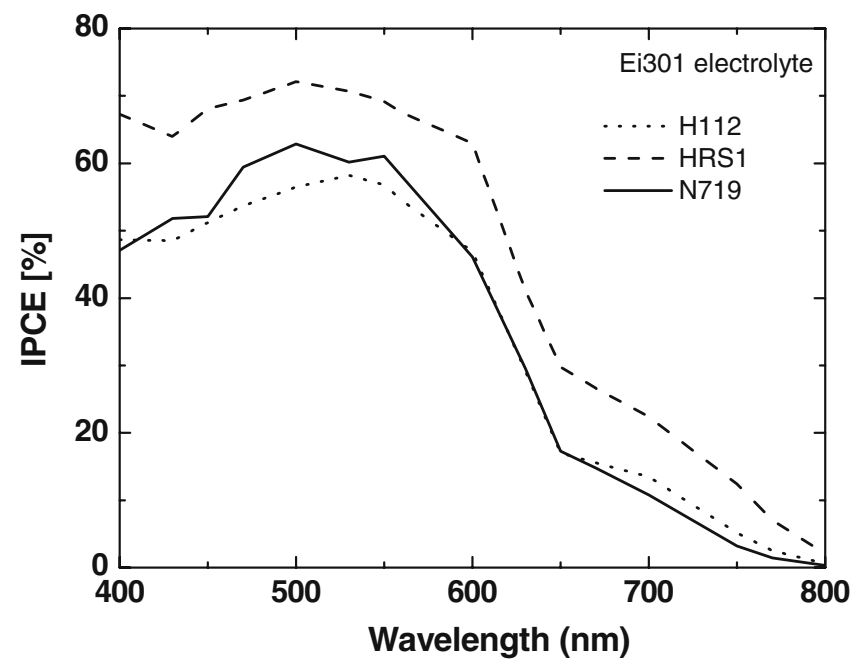

Figure 4. Photocurrent action spectra of devices fabricated from $0.74 \mathrm{~cm}^{2}$ active area $\mathrm{TiO}_{2}$ electrodes sensitized in dye solutions of ethanol and Ei301 electrolyte: LiI (1.0 M) and $\mathrm{I}_{2}(0.05 \mathrm{M})$ in $\gamma$-butyrolactone.

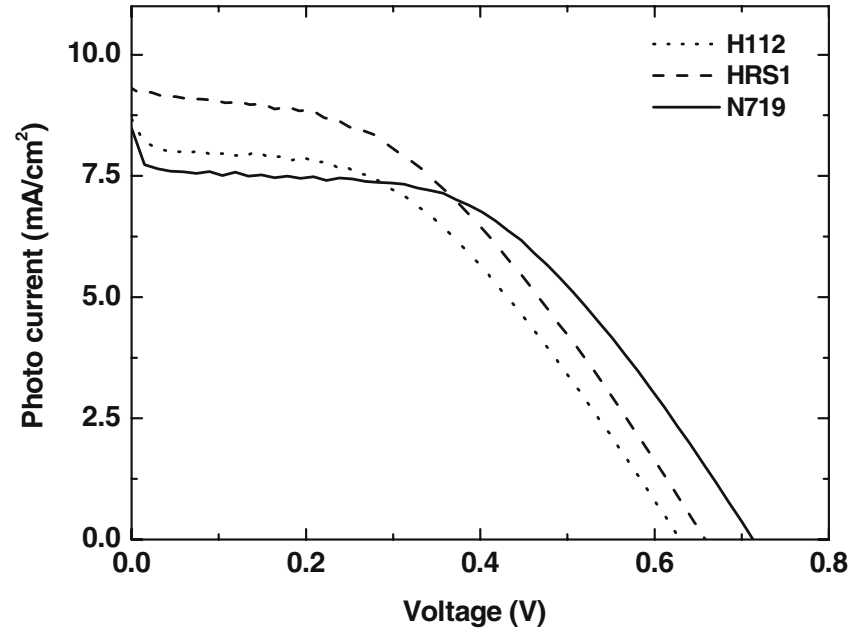

Figure 5. $\boldsymbol{J}-\boldsymbol{V}$ characteristics of DSSC devices fabricated from $0.74 \mathrm{~cm}^{2}$ active area $\mathrm{TiO}_{2}$ electrodes sensitized in dye solutions of ethanol measured under the irradiance of AM $1.5 \mathrm{G}$ sunlight of $100 \mathrm{~mW} \mathrm{~cm} \mathrm{~cm}^{-2}$.

incident photon-to-current conversion efficiencies of DSSCs fabricated with E6 electrolyte.

The IPCE spectra of HRS1 and H112 sensitizers resemble their absorption spectra adsorbed on $\mathrm{TiO}_{2}$ electrode and the IPCEs reached about 46 and $44 \%$ respectively while that of N719 sensitizer is almost equal to that of H112. The close observation of the IPCE spectra shows relatively higher and broader IPCE spectrum for HRS1 compared to H112 sensitizer. In DSC test cell, increasing LiI concentration of liquid electrolyte increases the exchange reaction between $\mathrm{I}^{-}$ and $\mathrm{I}_{3}{ }^{-}$which in turn increases charge transport rate and short-circuit photocurrent density. Therefore Ei301 electrolyte with a greater concentration of LiI was prepared, which would increase the charge transport rate and decreases $V_{\mathrm{OC}}$ due to shifting band edge towards positive. Hence Ei301 electrolyte has been explored to investigate IPCE of these sensitizers. The IPCE spectra of the DSSCs fabricated employing Ei301 electrolyte are shown in figure 4 As it is seen from the figure, HRS1

Table 1. Detailed photovoltaic parameters of DSSCs fabricated from $0.74 \mathrm{~cm}^{2}$ active area $\mathrm{TiO}_{2}$ electrodes sensitized in dye solutions of ethanol medium using E6 electrolyte.

\begin{tabular}{lcccc}
\hline Dye & $\boldsymbol{J}_{\mathrm{SC}}\left(\mathrm{mA} \mathrm{cm}^{-2}\right)$ & $\boldsymbol{V}_{\mathrm{OC}}(\mathrm{V})$ & $\mathbf{f f}$ & $\boldsymbol{\eta}(\%)$ \\
\hline H112 & 8.96 & 0.631 & 0.430 & 2.43 \\
HRS1 & 9.41 & 0.651 & 0.410 & 2.51 \\
N719 & 8.62 & 0.705 & 0.455 & 2.74 \\
\hline
\end{tabular}


shows higher IPCE of $72 \%$ as compared to $62 \%$ and $57 \%$ obtained for N719 and H112 sensitized solar cells.

In order to see whether the decreased spectral response is due to differences in packing densities of these dye molecules adsorbed on $\mathrm{TiO}_{2}$ surface, the film absorption ratio versus normalized molar extinction coefficient plots were studied (figure S5, ESI), in which the absorption maxima of each dye was normalized with the absorption maxima of N719 while the molar extinction coefficients of these sensitizers are normalized with that of the molar extinction coefficient of N719. The film absorption ratios of $\mathbf{H} 112$ and HRS1 sensitizers are close to each other but are below to the hypothetical diagonal line indicating relatively lower packing densities of these sensitizer as compared to that of N719. The lower film absorption of these sensitizers could be because of the literally larger diameter of these complexes as compared to N719. The difference in the film absorption ratios in-between $\mathbf{H} 112$ and HRS1 is very small indicating that these molecules have similar packing densities, which indicates that decreased IPCE of $\mathbf{H} 112$ relative to HRS1 could not be due to the higher surface unsaturation of $\mathrm{TiO}_{2}$ electrodes. Compared to H112 sensitized solar cell, HRS1 showed broader and higher IPCE spectrum resulting from its high light harvesting capability. Furthermore, sulfur has greater radial extension in its bonding than the second-row elements such as carbon. Thiophene being a more electron-rich moiety, incorporation of thiophene onto bipyridine ligands in HRS1 can raise the energy levels of the metal center and the LUMO of the ligands. As a consequence, the absorption band corresponding to metal to anchoring ligand transition is red shifted as compared to the H112 ligand, which may contribute for broader IPCE spectrum of HRS1.

The photocurrent-voltage $(\boldsymbol{J}-\boldsymbol{V})$ curves of three DSSCs fabricated using H112, HRS1 and N719 sensitizers and the corresponding photovoltaic performances are listed in figure 5 and table 1 . The shortcircuit photocurrent density (JSc), open-circuit voltage $\left(V_{\mathrm{Oc}}\right)$, and fill factor (ff) of the device with the H112 sensitizer under AM $1.5 \quad\left(100 \mathrm{~mW} \mathrm{~cm}^{-2}\right)$ irradiation are $8.96 \mathrm{~mA} / \mathrm{cm}^{2}, 631 \mathrm{mV}$, and 0.430 , respectively, which gives an overall conversion efficiency $(\eta)$ of $2 \cdot 43 \%$. When $J_{\text {sc }}$ is compared to that of $\mathbf{N} 719$ based DSSC, the device with sensitizer HRS 1 shows little higher $\boldsymbol{J}_{\mathrm{Sc}}$ value, which is consistent to its higher IPCE value. As HRS1 sensitizer showed broadened and increased IPCE response, a higher $\boldsymbol{J}_{\mathrm{SC}}$ value of $9 \cdot 41 \mathrm{~mA} / \mathrm{cm}^{2}$ was obtained among these sensitizers.

Short-circuit photocurrent density (Jsc), open-circuit photovoltage (Voc), fill factor (ff) values of cell parameters specified are average of three DSSCs fabricated under identical conditions. Error in $\mathrm{JSC} \pm$ $0 \cdot 5, \mathrm{VOC} \pm 0 \cdot 03, \mathrm{ff} \pm 0 \cdot 05$

\section{Conclusions}

In summary, the novel cis-Ru(II)(4,4'-bis(4-tert-butylstyryl)-2,2'-bipyridyl) (4,4'-dicarboxy-2,2'-bipyridyl) $\left(\mathrm{NCS}_{2}\right)(\mathbf{H} 112)$ was synthesized and characterized using the spectroscopic techniques. The sensitizer showed improved molar absorptivity and reversible one electron oxidation process as compared to N719 sensitizer. The DSSC constructed based on this sensitizer gave comparable solar light to electricity conversion efficiency. Synthesis of new ruthenium(II) sensitizers based on variations in bipyridine ancillary ligands is under progress.

\section{Supporting information}

The electronic supporting information can be seen in www.ias.ac.in/chemsci.

\section{Acknowledgements}

The authors thank Aisin Cosmos R\&D Co. Ltd. for financial support. ST and ARM thank Council of Scientific and Industrial Research (CSIR) for Junior Research Fellowship.

\section{References}

1. Hubbert, M K 1949 Energy from fossil fuels. Science 109103

2. Hubbert M K 1981 The world's evolving energy system. Am. J. Phys. 491007

3. Bartlett A A 1986 Sustained availability: A management program for non-renewable resources. Am. J. Phys. 54398

4. Dresselhaus M S and I L Thomas 2001 Alternative energy technologies. Nature 414332

5. Campbell C J 2002 Petroleum and people Population and Environment 24193

6. Myers N and Kent J 2003 New consumers: The influence of affluence on the environment. Proc. Natl. Acad. Sci. U.S.A. 1004963

7. Ragauskas A J, Williams CK, Davison B H, Britovsek G, Cairney J, Eckert C A, William J Frederick J, Hallett J P, 
Leak D J, Liotta CL, Mielenz J R, Murphy R, Templer R and Tschaplinski T 2006 The path forward for biofuels and biomaterials Science 484

8. Barnham K W J, Mazzer M and Clive B 2006 Nat. Mater. 5161

9. Lewis N S, Crabtree G W, Nozik A J, Wasielewski M R and Alivisatos A P 2007 Basic energy sciences report on basic research needs: feature article. J. Phys. Chem. C 111 7,2853

10. Graetzel M 2001 Nature, 414

11. O’Regan B and Graetzel M 1991 Nature 353737

12. Nazeeruddin M K, Kay A, Rodicio I, Humphry-Baker R, Muller E, Liska P, Vlachopoulos N and Greatzel M 1993 J. Am. Chem. Soc. 1156382

13. Zakeeruddin S M, Nazeeruddin M K, Humpry Baker R, Pechy P, Quagliotto P, Barolo C, Viscardi G and Grätzel M 2002 Langmuir 18952

14. Wang P, Zakeeruddin SM and Grätzel M 2003 Nature Materials 402

15. Ajayaghosh A, Carol $\mathrm{P}$ and Sreejith S $2005 \mathrm{~J}$. Am. Chem. Soc. 12714962

16. Sreejith S, Divya K P and Ajayaghosh A 2008 Chem. Commun. 2903

17. Divya K P, Sreejith S, Balakrishna B, Jayamurthy P, Aneesa P and Ajayaghosh A 2010 Chem. Commun. 466069

18. Wang P, Zakeeruddin S M, Moser J E, Humphry-Baker R, Comte P, Aranyos V, Hagfeldt A, Nazeeruddin M K and Grätzel M 2004 Adv. Mater. 161806

19. Wang P, Klein C, Humphry Baker R, Zakeeruddin S M and Grätzel M 2005 J. Am. Chem. Soc. 127808

20. Kuang D, Klein C, Ito S, Moser E J, Humphry-Baker R, Zakeeruddin S M and Grätzel M 2007 Adv. Funct. Mat. 17154

21. Ke-Jian J, Naruhiko M, Jiang-bin X, Shuji N and Shozo Y 2006 Chem. Commun. 2460

22. Chia-Yuan C, Shi-Jhang W, Chun-Guey W, Jian-Ging C and Kuo-Chuan H 2006 Angew. Chem. Int. Ed. 1185954

23. Kuang D, Klein C, Ito S, Moser J E, Humphry-Baker R, Evans N, Duriaux F, Grätzel M, Zakeeruddin S M and Gratzel M 2007 Adv. Mater. 191133

24. Kaung D, Klein C, Zhang Z, Ito S, Moser J E, Zakeeruddin S M and Grätzel M 2007 Small 32094

25. Mater F, Ghaddar T H, Walley K, DosSanto T, Durrant J R and O’ Regan B 2008 J. Mater. Chem. 184246
26. Yming C, Yu B, Qingjiang Y, Yueming C, Shi L, Dong S, Feifei G and Peng W 2009 J. Phys. Chem. C 1136290

27. Feifei G, Yueming C, Qingjiang Y, Shi L, Dong S, Yunhui L and Peng W 2009 Inorg. Chem. 482664

28. Gao F, Wang Y, Shi D, Zhang J, Wang M, Jing X, Humphry Baker R, Wang P, Zakeeruddin S M and Grätzel M 2008 J. Am. Chem. Soc. 13010720

29. Giribabu L, Vijay Kumar C, Srinivasa Rao C, Gopal Reddy V, Yella Reddy P, Chandrasekharam M and Soujanya Y 2009 Energy \& Environ. Sci. 2770

30. Kuang D, Ito S, Wenger B, Klein C, Moser J E, Humphry Baker R, Zakeerudddin S M and Grätzel M 2006 J. Am. Chem. Soc. 1284146

31. Kuang D, Klein C, Snaith H J, Moser J E, Humphry Baker R, Comte P, Zakeeruddin S M and Grätzel M 2006 Nano Lett. 6769

32. Aranyos V, Hjelm J, Hagfeldt A and Grennberg H 2003 Dalton Trans., 1280

33. Chen C Y, Wu S J, Wu C G, Chen J G and Ho K C 2006 Angew. Chem. Int. Ed. 455822

34. Giribabu L, Chandrasekharam M, Lakshmikantam M, Reddy V G, Satyanarayana D, Rao O S and Reddy P Y 2006 Indian J. Chem. Sec. A, 45629

35. Reddy P Y, Giribabu L, Lyness Ch, Snaith H J, Vijaykumar $\mathrm{Ch}$, Chandrasekharam M, Lakshmikantam M, Yum J H, Kalyanasundaram K, Grätzel $\mathrm{M}$ and Nazeeruddin M K 2007 Angew. Chem. Int. Ed. 46373

36. Giribabu L, Vijaykumar Ch, Reddy V G, Reddy P Y, Rao Ch S, Jang S -R, Hum J H, Nazeeruddin M K and Grätzel M 2007 Sol. Energy Mater. Sol. Cells 911611

37. Bennett M A, Huang T N, Matheson T W and Smith A K 1982 Inorganic Syntheses 2174

38. Matt Law, Lori E Greene, Justin C, Johnson, Saykally Richard and Yang Peidong 2005 Nature materials, 4 455

39. Suh D I, Lee S Y, Kim T H, Chun J M, Suh E K, Yang O B and Lee S K 2007 Chem. Phys. Lett. 442348

40. Sheng Qiang F, Chang-Jiu L, Guan-Jun Y, Ling-Zi Z, Jin-Cheng G and Ying-Xin X 2007 J. Thermal Spray Technol. 16893

41. Kawano R, Matsui H, Matsuyama C, Sato A, Susan M A B H, Tanabe N and Watanabe M 2004 J. Photochem. and Photobiol. A: Chemistry 16487 